\title{
JOHN ROBERT FOSTER
}

BORN in Sleights, Yorkshire, in 1868. John Robert Foster qualified at Edinburgh in 1893. After holding House appointments at the Central London and Royal Westminster Ophthalmic and at the Golden Square Nose and Throat Hospitals, he was appointed as Ophthalmic Surgeon at the Hartlepools Hospital. A year later he was appointed as Ophthalmic Surgeon to the Cameron and Howbeck House. Hospitals and the Hartlepools Education Authority as Aural and Ophthalmic Surgeon. He served in this capacity, being an excellent and careful surgeon, until at the age of 64 he had to retire from hospital and private practice owing to ill-health. His death occurred suddenly at the age of 81 , at Danby, on August 5, 1949. He is survived by a widow and three children, the eldest of whom is Ophthalmic Surgeon to the General Infirmary at Leeds.

J. F.

\section{FRIEDRICH P. FISCHER}

THE death of Friedrich P. Fischer on July 23, 1949, at the age of 52 , robs ophthalmology of one of its outstanding research workers. Fischer's interest lay mainly in the basic sciences, particularly in physical chemistry. Much of his earlier work was summarised in his remarkable contribution on The Water Content of the Eye, published in Locumenta Ophthalmologica in 1938. The bearing of this highly abstruse work on glaucoma and on retinal detachment is obvious, and though Fischer could give no final answer, the work he has done is a permanent contribution to an exceptionally difficult subject. An equally important contribution bearing on the same clinical problems is represented by his recent paper on The Mechanical Properties of the Eye and its Tissues. His investigations on mycellia have a direct bearing on detachment, whilst his studies on elasticity and rigidity may ultimately help to clarify the problems of glaucoma.

Fischer's professional career was twice interrupted by the emergence of the Nazi horror. After 1933 there was no room for Fischer and his like in a Germany where all civilised values had collapsed. Through the wisdom of Professor Weve, Fischer found a congenial home at the Clinic at Utrecht. When he went to Utrecht at the age of 36 he took with him an international reputation in his own sphere based on over 40 publications, and his subsequent industry brought lustre even to the Utrecht Clinic with its great traditions. The occupation of Holland by the Nazis in 1940 interrupted Fischer's career for a full five years. With the 
help of the highly organised Dutch resistance movement, and several false passports, he managed to elude the Gestapo, learning in the process how to trap rabbits in the woods, and to subsist on stolen chickens and stream-water. In the four years that were left to him at the end of the war he returned with renewed enthusiasm to his single-hearted devotion to research. A man of wide culture, he contributed to the study of the history of ophthalmology, as shown by his excellent paper on Goethe. He became one of the editors, and the leading spirit, of the revived Documenta Ophthalmologica and of the ophthalmic volumes in Tabulae Biologicae. In his work he was greatly assisted by his wife and his colleague, Dr. H. von Bunau. To her and to their two daughters goes out the sympathy of the profession at large.

A.S.

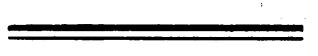

\section{NOTES}

International

Exchange of

Publications

A MANUal on the International Exchange of Publications will be published this year by Unesco Clearing House for Publications, 19, Avenue Kléber, Paris 16e. Annexed to this manual will be a classified list of institutions willing to exchange their own publications, or publications regularly at their disposal. Relevant details, which should reach Unesco by October 1, 1949, are (a) name and address of institution (e.g., library, university, learned society) ; (b) titles of publications offered; (c) any special conditions of exchange.

\footnotetext{
The Professor of Ophthalmology, Faculty of University of Toronto Medicine, University of Toronto, announces a 3-year post-graduate course in ophthalmology. Appointments are made in December, and work begins on the following July 1. A successful candidate is granted a special Fellowship worth approximately $\$ 1400$, which enables him to devote the first year to one of the basic sciences of ophthalmology. He spends the other two years on the intern service of one or more of the University teaching hospitals, but must attend courses of instruction by members of the staff. Such teaching occupies about four hours a week from October to May, and the fee payable is $\$ 50$ a year. Senior interns are taught how to prepare and deliver scientific papers.
} 